\title{
Identification and functional analysis of an alternative promoter of human intersectin 1 gene
}

\author{
S. V. Kropyvko, L. O. Tsyba, I. Ya. Skrypkina, A. V. Rynditch
}

Institute of Molecular Biology and Genetics NAS of Ukraine

150, Akademika Zabolotnogo Str., Kyiv, Ukraine, 03680

rynditch@imbg.org.ua

\begin{abstract}
Aim. Intersectin 1 (ITSN1) gene encodes an evolutionarily conserved adaptor protein that functions in clathrin-mediated endocytosis, cell signalling, apoptosis and cytoskeleton rearrangements. Its expression is characterized by multiple alternative splicing. Alternative promoter usage is an additional way to create diversity and flexibility in the regulation of gene expression. The aim of this study was to identify possible alternative promoters of ITSN1 gene. Methods. In silico prediction, 5' RACE, RT-PCR and reporter gene expression assay were used for identification and functional characterization of alternative promoter region. Results. We detected an alternative promoter of human ITSN1 gene which is located in intron 5 and generates $5^{\prime}$ truncated transcripts containing in-frame ATG codon with strong Kozak sequence and could encode an N-terminally truncated isoforms lacking first EH domain. The region located 246-190 bp upstream of exon 6 is required for alternative promoter activity. ITSN1 transcripts generated from an alternative promoter were detected in human kidney, liver, lung and brain tissues. However, the level of their expression was significantly lower than that of major ITSN1 isoforms. Conclusion. The results obtained suggest that alternative promoter region located in intron 5 of ITSN1 gene functions as a weak promoter. Further experiments are required to clarify the role of 5' truncated ITSN1 transcripts.
\end{abstract}

Keywords: intersectin 1, alternative promoter, alternative splicing, 5' UTR, adaptor proteins.

Introduction. Intersectin 1 (ITSN1) is a conserved adaptor protein implicated in clathrin-mediated endocytosis, apoptosis, signal transduction and cytoskeleton organization (for a review see [1]). Its expression is characterized by multiple alternative splicing [2-4]. The major ITSN1 protein isoforms described in mammals are ubiquitously expressed short form, ITSN1-S, and the long form, ITSN1-L, that is mainly expressed in neurons. The short form consists of two N-terminal Eps15 homology domains (EH1 and EH2), a coiledcoil region and five Src homology domains (SH3 AE). The long form contains C-terminal extension with a Dbl homology (DH), a pleckstrin homology (PH), and a C2 domains [1]. Recently, we described 15 additional

(C) Institute of Molecular Biology and Genetics NAS of Ukraine, 2010
ITSN1 transcriptional isoforms generated by different combinations of alternatively spliced exons [5].

Several lines of evidence suggested that a large fraction of human genes possesses multiple promoters which could be regulated in a different manner and complements alternative splicing in generating different protein isoforms [6]. Here we report the identification of an alternative promoter of ITSN1 gene which is located in intron 5 and generates $5^{\prime}$ truncated ITSN1 transcripts.

Materials and methods. $R N A$ isolation and $R T$ $P C R$. Total RNA from human tissues was isolated as described previously [5]. cDNA was synthesized from 1 to $5 \mu \mathrm{g}$ of total RNA using oligo(dT) primer and Expand Reverse Transcriptase («Roche», France). Five percent of the cDNA obtained was used as a template 
for PCR as described previously [5]. The following oligonucleotides were used for expression analysis of transcripts generated from an alternative promoter: exon 5 , forward -

\section{3-ATCAGCTACCCTCTGCACTTCC-564;}

exon 9 , reverse -

1041-TGAGCCTGTGGTAAACTTGACTGC-1018;

AP210, forward -

35122238-GTTCTGTCTTCAGGTTGAGTC-35122258;

$\beta$-actin, forward -

5'-GAAATCGTGCGTGACATTAAG-3';

$\beta$-actin, reverse -

5'-AAGCATTTGCGGTGGACGATGGAG-3';

GAPDH, forward -

5'-TGAAGGTCGGAGTCAACGGATTTGGT-3';

GAPDH, reverse -

5'-CATGTGGGCCATGAGGTCCACCAC-3'.

For the detection of alternative splicing events in the 5' UTR the following oligonucleotides were used:

exon 1 , forward -

2-AGCAAGCTTGGGAGCGAAGGAGGT-25;

exon 1a, forward -

35061642-TTCCCAAATGCGGCATCTGTGT-35061663; exon $1 \mathrm{~b}$, reverse -

35088748-GGGGTGTGAAGTGATCAACTCA-35088769; exon 6 , reverse -

730-AGCTGCTGTGGGAACAGAAGAT-709.

Nucleotide positions for oligonucleotides are based on the ITSN1-L and ITSN1-S cDNAs and genomic sequence of chromosome 21 (GenBank accession numbers NM_001001132.1, NM_003024.2 and NC_ $000021.8)$.

$5^{\prime} R A C E$ was performed using human fetal brain and lung total RNAs and the 5'/3' RACE kit («Roche») according to the manufacturer's instructions. The primers used for 5' RACE were 5'-GGCCACATCAAATG ACTGT-3' and 5'-ATTTCTTGCCTTTGGGTGGTC-3'.

Cell culture and transfection. The cell lines HeLa and HEK293 were grown at $37{ }^{\circ} \mathrm{C}$ in $5 \% \mathrm{CO}_{2}$ in Dulbecco's modified Eagle's medium supplemented with $10 \%$ fetal bovine serum, $50 \mathrm{U} / \mathrm{ml}$ penicillin and $100 \mu \mathrm{g} / \mathrm{ml}$ streptomycin. The cells were transfected using JetPEI (Polyplus Transfection). Cells grown in 12-well plates at 60-70\% confluence were transfected in duplicate with $3 \mu \mathrm{g}$ reporter gene constructs and $300 \mathrm{ng}$ of Renilla luciferase expression vector, $p R L-T K$. Cells were collected $42 \mathrm{~h}$ after transfection. Cell extracts were assayed for Firefly and Renilla luciferase activities using the Dual Luciferase Reporter Assay System («Promega», USA) and VICTOR3 Multilabel Counter 1420 («PerkinElmer», USA). Relative luciferase activities were determined as the ratio of Firefly luciferase activity of each sample to Renilla luciferase activity.

Plasmids. For Dual Luciferase Reporter Assay, PCR products corresponding to the regions of intron 5 of ITSN1 gene were subcloned upstream the luciferase gene in $p G L 3$-basic expression vector («Promega»). All PCR-generated DNA fragments were sequenced to confirm fidelity.

Results and Discussion. Identification of alternative transcription start sites in the human ITSN1 gene. To search the putative alternative promoters of ITSN1 gene we analyzed database of transcription start sites, DBTSS, based on experimentally determined $5^{\prime}$ end clones [7] and found two clones with putative transcription start sites located in introns 5 and 12. Then we performed 5' RACEs on human fetal lung and brain total RNAs with antisense primers within exons 6 and 13. Discrete bands were obtained only with primers specific to exon $6.5^{\prime}$ ends of RACE products were located 343,323 and 285 bp directly upstream of the exon 6 (Fig. 1, $A$ ).

To verify the obtained results and more precisely map possible transcription start sites, RT-PCRs with different sense primers located at positions 36, 210, 338,415 and 526 bp upstream of exon 6 and antisense primer within exon 9 were performed. The results suggest that alternative transcription start sites are located at positions between 285-415 bp upstream of exon 6 (Fig. 1, $B$ ). The $5^{\prime}$ end of the longest $5^{\prime}$ RACE product was designated as +1 . Sequence analysis revealed the alternative in-frame ATG codon located in exon 6 (at position +347 bp) that contains strong Kozak sequence (GGTATGG) and could be considered as good candidate for the initiation of the translation. The resulting ORF could encode an N-terminally truncated version of ITSN1 that lacks first EH domain.

Functional conformation of alternative promoter region using reporter gene analysis. To determine whether the putative alternative promoter region has functional promoter activity, three fragments of the 


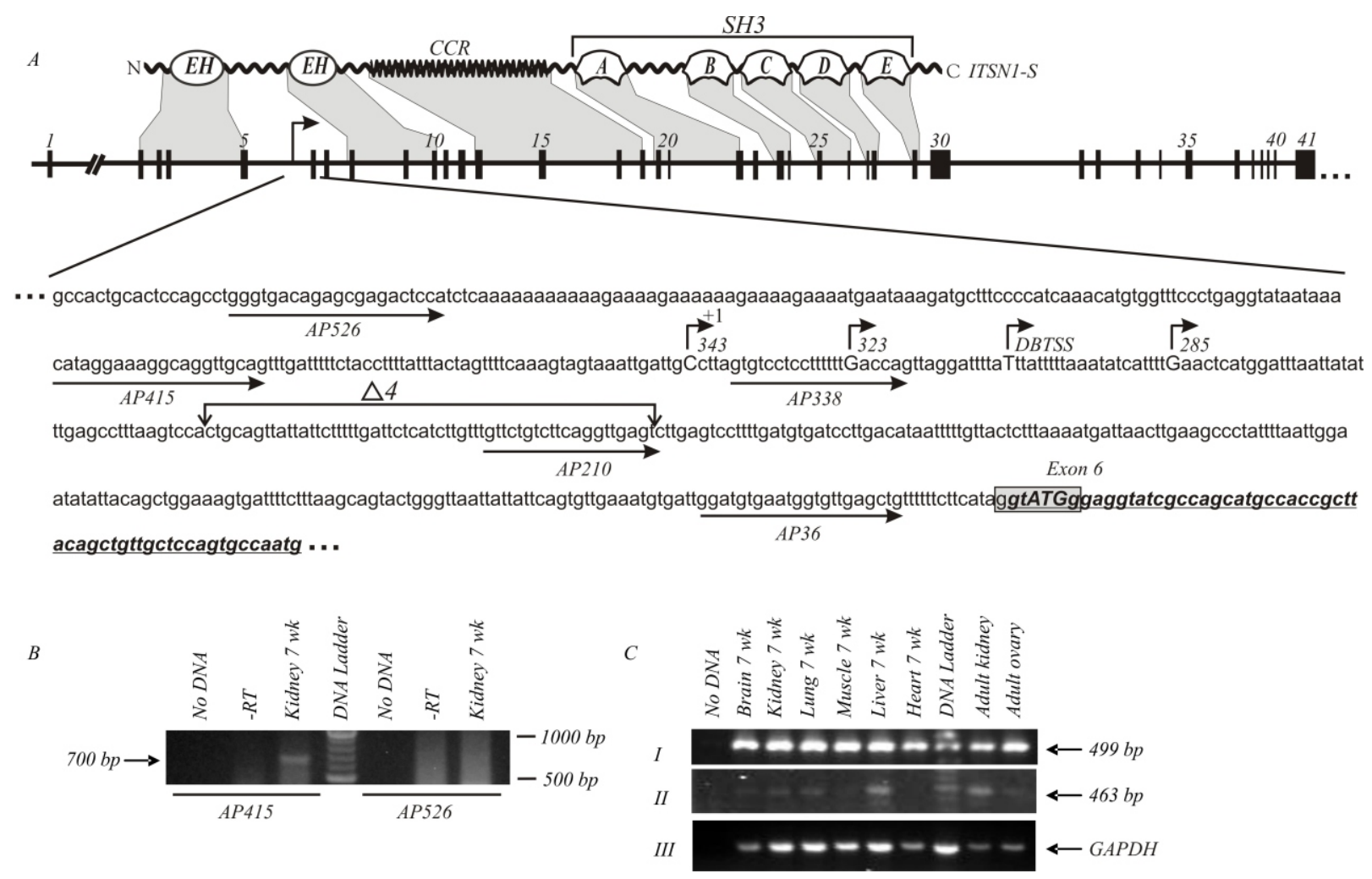

Fig. 1. A-scheme of ITSN1 gene with domain organization of short isoform (exons of ITSN1 gene are numbered; partial sequence of intron 5 and exon 6 of human ITSN1 gene is shown; sequence of exon 6 is underlined; positions of 5' ends of RACE products as well as transcription start site predicted by DBTSS are indicated as arrows above the sequence; primers for 5' end mapping are indicated by arrows below the sequence; consensus Kozak sequence is boxed; region required for promoter activity $(\Delta 4)$ is indicated by figure arrows above the sequence); $B$ - mapping of the 3 ' end of ITSN1 transcripts generated from an alternative promoter using RT-PCR with AP415 and AP526 primers (control reactions without reverse transcriptase (-RT) are shown); $C$-analysis of expression of ITSN1 transcripts produced from the major $(I)$ and alternative $(I I)$ promoters and control GAPDH gene (III) in fetal and adult human tissues; wk - week of fetus

intron 5 spanning the region from -1157 to $+153 \mathrm{bp}$ were cloned into the promoterless $p G L 3$-basic vector upstream of the firefly luciferase coding sequence (Fig. $2, A)$. Alternative promoter activity was analyzed in HeLa and HEK293 cells in comparison with control promoter of the herpes simplex virus thymidine kinase $(p T K-L u c)$ and major ITSN1 promoter located upstream of exon $1(-997+86 \mathrm{bp})$. The results of the luciferase assays showed that all three alternative promoter constructs were able to drive reporter gene expression in both cell lines. In HEK293 cells the activity of alternative promoter constructs was higher than in HeLa, however it was approximately 3,5-fold lower than the activity of TK promoter and 1,8-fold lower than that of the major ITSN1 promoter. In HeLa cells alternative promoter activity was 10 -fold lower than the activity of the major promoter.

Mapping the regions of promoter activity. We generated a series of deletion constructs in order to loca- lize regulatory sequence elements and the minimal promoter region. Deletion of the region located between +97 and -23 bp did not result in significant decrease of luciferase activity (Fig. 2, B). When HEK293 cells were transfected with $p A P-283 \Delta 1, p A P-283 \Delta 2, p A P-$ $667 \Delta 8, p A P-667 \Delta 6$ and $p A P-1157 \Delta 7$ constructs, the promoter activity was slightly increased, thereby suggesting the presence of a negative regulatory element located between -675 and -23 bp. However, deletion of the segment between +97 and +153 bp caused marked decreases of luciferase activity. These results imply that the +97 to +153 bp region is required for alternative ITSN1 promoter activity.

Analysis of expression of ITSN1 transcripts generated from an alternative promoter. The mammalian ITSN1 gene produces two major isoforms, ITSN1-S and ITSN1-L [1]. To analyze the expression of ITSN1 transcripts produced from an alternative promoter, nested RT-PCRs using a sense primer of intron 5 and 


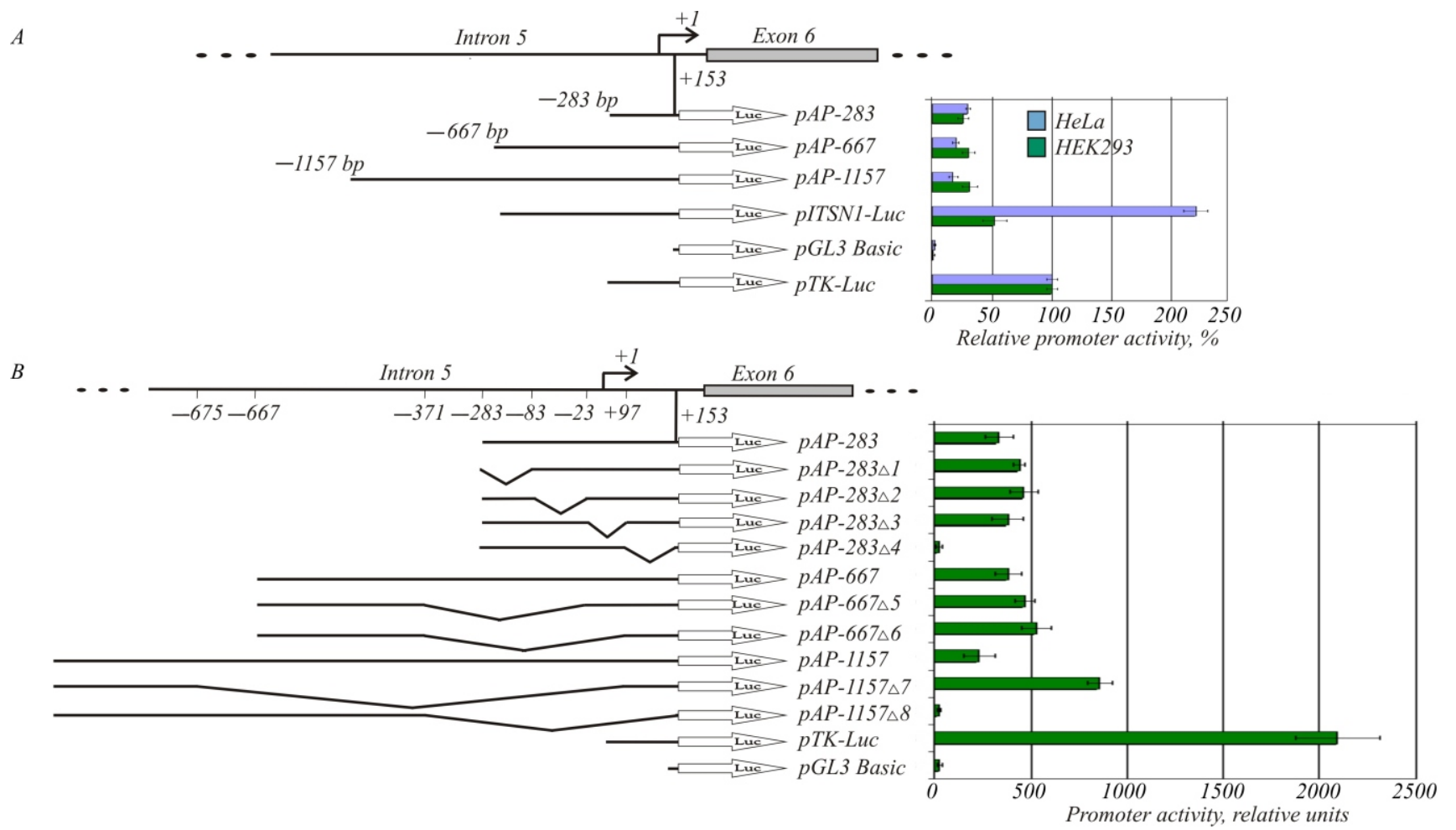

Fig. 2. A - activity of ITSN1 alternative promoter in HeLa and HEK293 cells (cells were transfected with sequentially deleted reported constructs of the $-1157+153 \mathrm{bp}$ sequence; transient transfection and luciferase assays were performed in triplicate; the data were normalized to renilla luciferase activity and are shown as relative activities compared to that for $p T K-L u c$; the mean values and standard deviations were calculated from three experiments); $B$ - mapping of ITSN1 alternative promoter region (deletion constructs of ITSN1 alternative promoter region used for luciferase assay in cell line HEK293 are indicated)

antisense primers specific for the short and long ITSNI isoforms were performed. PCR products were detected only with primers specific to ITSN1-S isoform. Subsequent cloning and sequencing of these products showed that they represent two different splice variants of ITSN1-S (Fig. 3). A first transcript was amplified from fetal kidney. It lacks exons 25 and 26 that encode the SH3C domain involved in interaction with prolinerich motifs of dynamin 1, synaptojanin 1, SOS1, WNK-kinase and other proteins [8-10]. The second transcript was detected in fetal lung tissue and was characterized by unusual for ITSN1 combination of alternatively spliced exons. It contains elongated exon 12 due to the use of an alternative $3^{\prime}$ splicing site located $22 \mathrm{nt}$ upstream of the $5^{\prime}$ end of exon 12 and lacks exons 25, 26 and 27. This combination of alternative splicing events shifts the open reading frame and introduces stop codons.

To examine further the expression of the ITSN1 transcripts, RT-PCR was performed on total RNAs from different tissues using primers specific for the amplification of ITSN1 mRNAs originating from the major and alternative promoters. The expression of ITSN1 transcripts generated from an alternative promoter was significantly lower than that of major ITSN1 isoforms. RT-PCR products of transcripts produced from an alternative promoter were observed in fetal kidney, liver, lung and brain, as well as in adult kidney and ovary (Fig. 1,C). However, a second step of PCR amplification with nested primers revealed the presence of these transcripts in all tissues tested indicating the low level of their expression (data not shown). RT-PCR analysis and results of luciferase assays suggest that identified alternative promoter region functions as a weak promoter. We could not use Western blot analysis to study the expression of ITSN1 proteins encoded by transcripts from an alternative promoter since the molecular weight of these proteins coincides with that of alternatively spliced ITSN1-22a isoform.

Alternative splicing affecting the 5' UTR of ITSN1 $m R N A$. 5' untranslated region (5' UTR) of human ITSN1 mRNA produced from the major promoter con- 


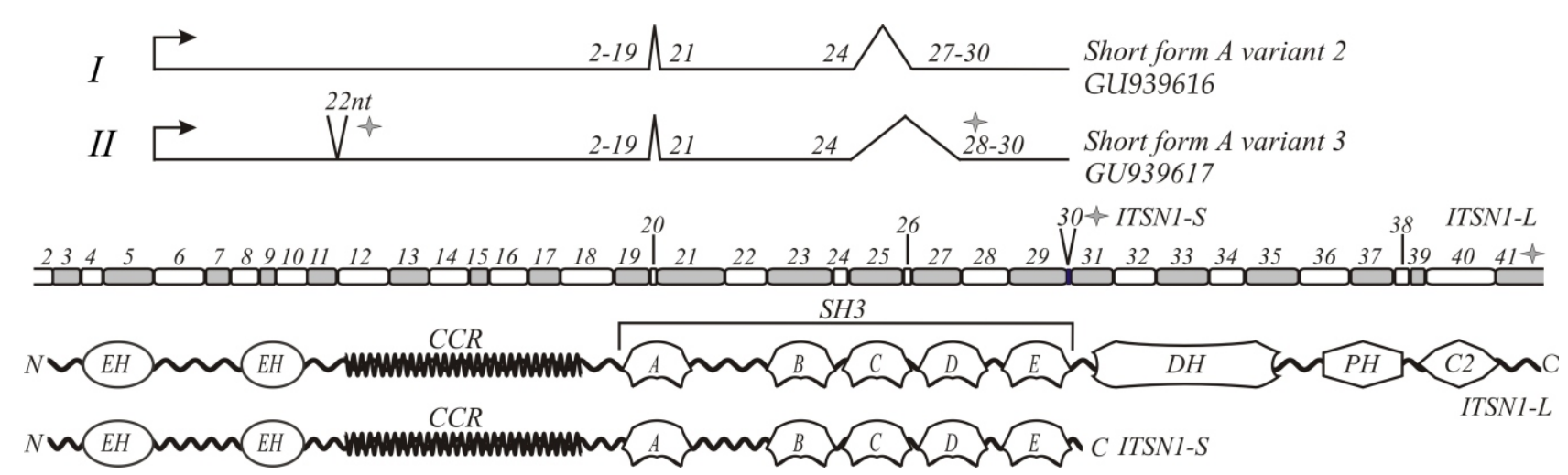

Fig. 3. Schematic representation of the ITSN1 transcripts produced from an alternative promoter $(I, I I)$ and domain structure of the two main isoforms, short (ITSN1-S) and long (ITSN1-L). ITSN1 exons are shown as black and white boxes and numbered above. Stop codons are marked by asterisks

$A$
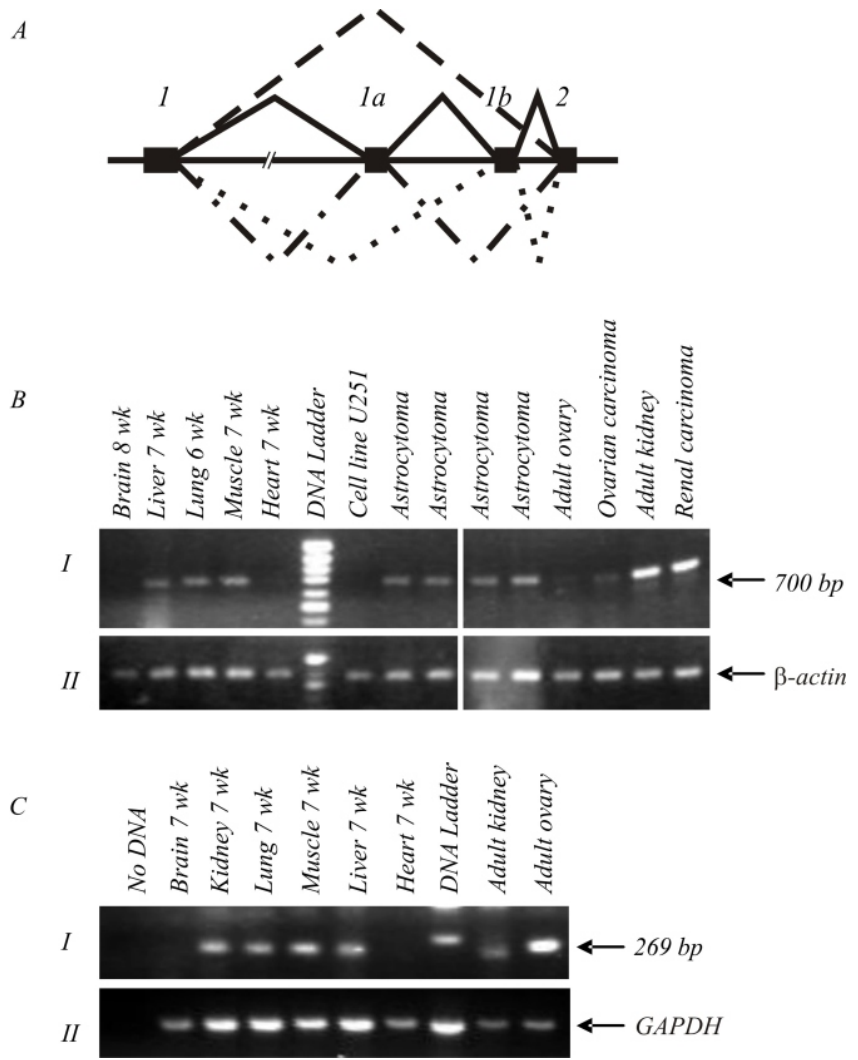

Fig. 4. $A$-schematic representation of splicing events affected 5 UTR of human ITSN1 mRNA; $B$ - analysis of expression of ITSN1 isoforms containing exon 1a using primers specific for exons $1 \mathrm{a}$ and 6 (BI); C - analysis of expression of ITSN1 isoforms containing exon $1 \mathrm{~b}$ using primers specific for exons 1 and $1 \mathrm{~b}(C I) ; B, C(I I)-$ analysis of expression of control genes $G A P D H$ and $\beta$-actin

sists of two exons and could start from seven different transcriptional start sites according to CAGE-tags database. While analyzing GenBank Database we found two ESTs that had high homology with human ITSN1 gene and carried two insertions of 62 and 187 bp lo- cated between exons 1 and 2 . The insertions are generated due to addition of two exons of 62 and $125 \mathrm{bp}$ that were designated as exons $1 \mathrm{a}$ and $1 \mathrm{~b}$ (Fig. $4, A$ ). The combination of exons $1 \mathrm{a}$ and $1 \mathrm{~b}$ resulted in an insertion of $187 \mathrm{bp}$. Start-codon of ITSN1 is located in exon 2 and addition of two supplementary exons expands the total length of 5' UTR of ITSN1 mRNA and potentially could affect translation efficiency, mRNA transport and stability.

To explore tissue specificity of ITSN1 transcripts with two supplementary exons, we performed RT-PCR and found that these isoforms are widely expressed in the majority of tissues without any significant tissue specificity (Fig. 4). Our further experiments showed that exons $1 \mathrm{a}$ and $1 \mathrm{~b}$ are predominantly spliced in a mutually exclusive fashion. Using primers within exons 1a and 6 we obtained PCR product of 700 bp that corresponds to the isoform containing exon $1 \mathrm{a}$, but failed to amplify the $825-\mathrm{bp}$ PCR product containing both exons $1 \mathrm{a}$ and $1 \mathrm{~b}$ (Fig. 4, $B$ ). To confirm these findings, we performed RT-PCR using sense primer within exon 1 and antisense primer specific to exon $1 b$. The results indicated the presence of the products of 269 bp representing the transcript with exon $1 \mathrm{~b}$ and absence of the 331-bp product corresponding to the isoforms containing exons $1 \mathrm{a}$ and $1 \mathrm{~b}$ (Fig. 4, C).

Thus, we identified alternative promoter of ITSN1 gene that generates novel transcript variants and therefore diversifies functions of endocytic adapter protein ITSN1. The data concerning alternative splicing events within $5^{\prime}$ UTR could be also important for further understanding of ITSN1 regulation at posttranscriptional level. 


\section{С. В. Кропивко, Л. О. Циба, І. Я. Скрипкіна, А. В. Риндич}

Ідентифікація та функціональний аналіз альтернативного промотору гена інтерсектину 1 людини

Резюме

Мета. Ген інтерсектину 1 (ITSN1) кодує еволюиійно консервативний адаптерний білок, причетний до клатрин-опосередкованого ендоцитозу, внутрішньоклітинної передачі сигналу, апоптозу та реорганізації иитоскелету. Його експресія пов 'язана з багатьмя подіями альтернативного сплайсингу. Додатковим способом досягнення різноманіття $і$ тонкої регуляиії експресії генів є пошук альтернативних промоторів. Мета роботи полягала у виявленні можливих альтернативних промоторів гена ITSN1. Методи. Застосоваано комп'ютерне передбачення, 5' RACE, RT-PCR і тест, оснований на аналізі експресії репортерного гена. Результати. Виявлено альтернативний промотор гена ITSN1 людини, локалізований у 5-му інтроні, внаслідок використання якого утворюються транскрипти 3 відкритою рамкою зчитування та консенсусною послідовністю Козак, здатні кодувати ITSN1-ізоформи без першого ЕН-домену. Визначено, щзо ділянка, розташована за 246-190 n. н. до початку 6-го екзона, необхідна для функиіонування альтернативного промотору. Транскрипти ITSN1, щуо утворюються в результаті використання альтернативного промотору, знайдено в тканинах нирок, печінки, легень і мозкулюдини, проте рівень їхньої експресії значно нижчий порівняно з основними ізоформами ITSN1. Висновки. Отримані дані свідчать про те, що альтернативний промотор, локалізований у 5-му інтроні гена ITSN1 людини, функиіонує як слабкий промотор. Подальші дослідження необхідні для з'ясування функиії транскриптів ITSN1 з альтернативним 5'-кінцем.

Ключові слова: інтерсектин 1, альтернативний промотор, альтернативний сплайсинг, адаптерні білки, 5' UTR.

\section{С. В. Кропивко, Л. А. Циба, И. Я. Скрипкина, А. В. Рындич}

Идентификация и функциональный анализ альтернативного промотора гена интерсектина 1 человека

Резюме

Цель. Ген интерсектина 1 (ITSN1) кодирует эволюичонно консервативный адаптерный белок, участвующий в клатрин-опосредованном эндоцитозе, внутриклеточной передаче сигнала, апоптозе и реорганизации циитоскелета. Его экспрессия характеризуется многочисленными событиями альтернативного сплайсинга. Дополнительным способом достижения разнообразия и тонкой регуляции экспрессии генов является использование альтернативных промоторов. Цель данной работы состояла в обнаружении возможных альтернативных промоторов гена ITSN1. Методы. Применены компьютерное предсказание, 5' RACE, RT-PCR и тест, основанный на анализе экспрессии репортерного гена. Результаты. Нами выявлен альтернативный промотор гена ITSN1 человека, локализованный в 5-м интроне, в результате использования которого образуются транскрипты с открытой рамкой считывания и консенсусной последовательностью Козак, способные кодировать изоформы ITSN1 без первого ЕН-домена. Показано, что участок, находящийся за 246-190 n. н. до начала 6-го экзона, необходим для функиионирования альтернативного промотора. Tранскрипты ITSN1, полученные с альтернативного промото- ра, обнаружены в тканях почек, печени, легких и мозга челове$\kappa a$, но уровень их экспрессии значительно ниже по сравнению $c$ основными изоформами ITSN1. Выводы. Полученные результаты свидетельствуют о том, что альтернативный промотор, локализованный в 5-м интроне гена ITSN1, функционирует как слабый промотор. Дальнейшие исследования необходимы для выяснения функции транскриптов ITSN1 с альтернативным 5'-кониом.

Ключевые слова: интерсектин 1, альтернативный промоmор, альтернативный сплайсинг, адаптерные белки, 5' UTR.

\section{REFERENCES}

1. Pechstein A., Shupliakov O., Haucke V. Intersectin 1: a versatile actor in the synaptic vesicle cycle // Biochem. Soc. Trans.-2010.-38, pt 1.-P. 181-186.

2. Tsyba L. O., Skrypkina I. Ya., Nikolaienko O. V., Ferenent G. O., Gordiyuk V.V., Gardiner K., Rynditch A. V. Alternative splicing of intersectin 1 gene pre-mRNA: expression of transcriptional isoforms // Biopolym. cell.-2004.-20, N 6.P. 515-523.

3. Pucharcos C., Casas C., Nadal M., Estivill X., de la Luna S. The human intersectin genes and their spliced variants are differentially expressed // Biochim. Biophys. Acta.-2001.1521, N 1-3.-P. 1-11.

4. Tsyba L., Gryaznova T., Dergai O., Dergai M., Skrypkina I., Kropyvko S., Boldyryev O., Nikolaienko O., Novokhatska O., Rynditch $A$. Alternative splicing affecting the SH3A domain controls the binding properties of intersectin 1 in neurons // Biochem. Biophys. Res. Communs.-2008.-372, N 4.P. 929-934.

5. Kropyvko S., Gerasymchuk D., Skrypkina I., Dergai M., Dergai O., Nikolaienko O., Rynditch A., Tsyba L. Structural diversity and differential expression of novel human intersectin 1 isoforms // Mol. Biol. Rep.-2009.-DOI 10.1007/s11033009-9824-8.

6. Singer G. A. C., Wu J., Yan P., Plass C., Huang T. H. M., Davuluri $R$. $V$. Genome-wide analysis of alternative promoters of human genes using a custom promoter tiling array // BMC Genomics.-2008.-9, N 349.-P. 1-15.

7. Yamashita R., Suzuki Y., Wakaguri H., Tsuritani K., Nakai K., Sugano S. DBTSS: DataBase of Human Transcription Start Sites, progress report 2006 // Nucl. Acids Res.-2006.-34.P. 86-89.

8. Yamabhai M., Hoffman N. G., Hardison N. L., McPherson P. S., Castagnoli L., Cesareni G., Kay B. K. Intersectin, a novel adaptor protein with two Eps15 homology and five Src homology 3 domains // J. Biol. Chem.-1998.-273, N 47.P. 31401-31407.

9. Tong X. K., Hussain N. K., de Heuvel E., Kurakin A., AbiJaoude E., Quinn C. C., Olson M. F., Marais R., Baranes D., Kay B. K., McPherson P. S. The endocytic protein intersectin is a major binding partner for the Ras exchange factor $\mathrm{mSos} 1$ in rat brain // EMBO J.-2000.-19, N 6.-P. 1263-1271.

10. He G., Wang H., Huang S., Huang C. Intersectin links WNK kinases to endocytosis of ROMK1 // J. Clin. Invest.-2007.117, N 4.-P. 1078-1087. 